Jurnal Keperawatan Silampari

Volume 5, Nomor 1, Desember 2021

e-ISSN: 2581-1975

p-ISSN: 2597-7482

DOI: https://doi.org/10.31539/jks.v5i1.2885

\title{
DEFISIENSI VITAMIN D DAN PAPARAN SINAR MATAHARI \\ YANG BERKAITAN DENGAN DEFISIENSI VITAMIN D PADA TENAGA KESEHATAN COVID-19
}

\author{
Maria Eka Patri Yulianti ${ }^{1}$, Noor Diah Erlinawati ${ }^{2}$ \\ Universitas Bengkulu ${ }^{1}$ \\ Rumah Sakit Umum Daerah Dr. M.Yunus Bengkulu² \\ mariaeka1@ gmail.com ${ }^{1}$
}

\begin{abstract}
ABSTRAK
Penelitian ini bertujuan untuk mengetahui gambaran defisiensi vitamin dan paparan sinar matahari terhadap defisensi vitamin D pada tenaga kesehatan COVID-19 di Kota Bengkulu. Metode penelitian ini merupakan studi deskriptif obervasional potong lintang atau cross-sectional yang menggunakan pendekatan survei atau eksploratif. Hasil penelitian menunjukkan distribusi frekuensi karakteristik subjek penelitian terbanyak berusi 40 tahun, dengan pekerjaan terbanyak adalah perawat. Riwayat penyakit terbanyak adalah alergi dan $75 \%$ dari subjek tidak memiliki riwayat penyakit. Riwayat konfirmasi positif COVID-19 sebanyak 16\%. Jumlah subyek dengan riwayat terpapar sinar matahari dengan rekomendasi sesuai adalah $48 \%$ dan yang memiliki riwayat paparan lebih dari rekomendasi sebanyak $27 \%$. Masih ada $24 \%$ subyek yang memiliki paparan sinar matahari yang rendah yaitu dibawah 15 menit. Berdasarkan hasil pemeriksaan kadar vitamin D hampir sebagian besar subyek penelitian yang merupakan tenaga kesehatan mengalami kondisi defisiensi 59,5\% dan insufisiensi sebanyak 37,8\%. Hubungan paparan sinar matahari dengan kadar Vitamin D3 darah $\mathrm{p}=0,175$ (fisher exact test) Hasil Korelasi kendall's tau_b yaitu $r=0,047, p=0,722$, usia vs kadar vitamin $D$ yaitu $r=0,246, p=0,141$, serta berat badan vs kadar vit $D$ yaitu $r=0,312, p=$ 0,060. Berdasarkan hasil pemeriksaan kadar vitamin D hampir sebagian besar subyek penelitian yang merupakan tenaga kesehatan mengalami kondisi defisiensi 59,5\% dan insufisiensi sebanyak 37,8\%. Simpulan, hubungan antara sinar matahari, usia dan berat badan dengan kadar vitamin $\mathrm{D}$ menunjukkan bahwa tidak signifikan namun hal ini mengindikasikan adanya variable lain yang memengaruhi keadaan defisiensi pada tenaga kesehatan.
\end{abstract}

Kata Kunci: COVID-19, Vitamin D, Paparan Sinar Matahari

\section{ABSTRACT}

This study aims to determine the description of vitamin deficiency and sun exposure to vitamin D deficiency in COVID-19 health workers in Bengkulu City. This research method is a cross-sectional or cross-sectional descriptive study using a survey or exploratory approach. The results showed that the frequency distribution of the characteristics of the research subjects was mostly 40 years old, with the most occupations being nurses. Most of the disease history was allergies, and $75 \%$ of the subjects had no history of the disease. A history of positive confirmation of COVID-19 is $16 \%$. The number of subjects with a history of exposure to the sun with appropriate 
recommendations was $48 \%$, and those with a history of exposure to more than the recommendation were $27 \%$. There are still $24 \%$ of subjects who have low sun exposure, which is under 15 minutes. Based on the examination results of vitamin D levels, most of the research subjects who were health workers experienced $59.5 \%$ deficiency and $37.8 \%$ insufficiency. The relationship between sun exposure and blood Vitamin D3 levels $p=0.175$ (fisher exact test) The results of the Kendall's tau_b correlation are $r=$ 0.047, $p=0.722$, age vs vitamin D levels are $r=0.246, p=0.141$, and bodyweight vs vitamin $D$ levels $D$ is $r=0.312, p=0.060$. Based on the examination results of vitamin $D$ levels, most of the research subjects who were health workers experienced $59.5 \%$ deficiency and $37.8 \%$ insufficiency. In conclusion, the relationship between sunlight, age, and body weight with vitamin D levels showed that it was not significant, but this indicated that other variables influenced the deficiency state of health workers.

Keywords: COVID-19, Vitamin D, Sun Exposure

\section{PENDAHULUAN}

Wabah penyakit Coronavirus baru 2019 (COVID-19) adalah pandemi dramatis global yang berdampak pada komunitas. Mempertimbangkan implikasi kesehatan dan beban ekonomi pandemi COVID-19, cara efektif mempercepat pemulihan dan mengurangi risiko dianggap sebagai kepentingan klinis dan ekonomi yang signifikan. Kekurangan vitamin D dapat ditemukan tidak hanya di negara-negara dengan empat musim, tetapi juga di negara-negara dengan paparan sinar matahari sepanjang tahun. Di Chicago, lebih dari setengah kasus COVID-19 dan sekitar 70\% kematian COVID-19 diamati pada individu Afrika-Amerika yang berisiko lebih besar mengalami defisiensi vitamin D (Ebadi \& Montano-Loza, 2020).

Vitamin D adalah zat gizi mikro yang sangat penting untuk membantu menjaga kesehatan tulang dan muskuloskeletal. Namun, penelitian terbaru telah menyoroti peran pendukung penting untuk vitamin $\mathrm{D}$ dalam fungsi sel kekebalan tubuh, terutama dalam memodulasi respons inflamasi terhadap infeksi virus. Pada tingkat sel, vitamin D memodulasi sistem imun adaptif dan bawaan melalui sitokin dan regulasi jalur pensinyalan sel. Reseptor vitamin D (VDR) ada pada sel imun T dan B, memodulasi proliferasi, penghambatan dan diferensiasi sel-sel ini (Vanherwegen et al., 2017). Dalam model eksperimental inflamasi yang diinduksi lipopolisakarida, vitamin D dikaitkan dengan konsentrasi lebih rendah sitokin proinflamasi interleukin-6 (IL-6), yang memainkan peran penting dalam COVID-19 (McGonagle et al., 2020). Calcitriol (1,25dihydroxyvitamin D3) memberikan dampak yang nyata pada sumbu ACE2/Ang (17)/MasR dengan meningkatkan ekspresi ACE2. ACE-2 adalah reseptor sel host yang bertanggungjawab untuk menengahi infeksi oleh SARS-CoV-2 (Ilie et al., 2020).

Ada banyak bukti bahwa berbagai penyakit tidak menular (hipertensi, diabetes, CVD, sindrom metabolik) berhubungan dengan kadar plasma vitamin D yang rendah. Komorbiditas ini, bersama dengan defisiensi vitamin D yang sering terjadi, meningkatkan risiko kejadian COVID-19 yang parah (Wu et al., 2018). Tingkat kematian COVID-19 yang dihitung dari 12 negara Eropa menunjukkan korelasi terbalik yang signifikan $(\mathrm{p}=0,046)$ dengan konsentrasi plasma rata-rata vitamin D2 (Laird et al., 2020). Paparan sistematik review sowah pada tahun 2017 menyatakan kejadian defisiensi vitamin D tinggi pada pekerja paruh waktu dan di dalam ruangan. Defisiensi terutama secara berurutan terjadi pada siswa bidang kesehatan, residen dokter dan perawat (Sowah et al., 2017). Hasil sistematik review Coppeta tahun 2018 menyatakan 
bahwa pekerja shift dan pekerja dalam ruangan secara konsisten dilaporkan sebagai kelompok pekerjaan yang paling menderita kekurangan vitamin D3, termasuk para profesional tenaga kesehatan, pekerja rumah tangga dan eksekutif (Coppeta et al., 2018).

Penelitian mengenai prevalensi defisiensi vitamin D di Indonesia masih belum banyak dilakukan karena dianggap sebagai negara yang kaya sinar matahari sepanjang tahun. Penyebab utama defisiensi vitamin D adalah kurangnya pajanan sinar matahari, sehingga sintesis vitamin D di kulit menurun. Selain itu kebutuhan tubuh akan vitamin D tidak dapat seluruhnya dipenuhi dari asupan sumber bahan makanan, karena jumlah bahan makanan yang mengandung vitamin D sangat sedikit, disamping itu makanan yang telah difortifikasi vitamin $\mathrm{D}$ belum cukup untuk memenuhi kebutuhan tubuh (Parva et al., 2018; Nakhaee et al., 2019). Data tenaga kesehatan positif COVID di Provinsi Bengkulu menunjukkan jumlah 36 orang atau sekitar $23 \%$ jumlah positif yang telah terdeteksi. Penyebaran COVID-19 didominasi oleh tenaga kesehatan, sehingga hal tersebut menjadi perhatian khusus untuk meningkatkan imunitas dan komorbiditas akibat covid pada tenaga kesehatan. Penelitian ini masih jarang dilakukan, belum pernah ada penelitian yang sama dengan penelitian yang dilakukan, khususnya di tempat penelitian.

\section{METODE PENELITIAN}

Penelitian ini merupakan studi deskriptif obervasional potong lintang atau krosseksional yang menggunakan pendekatan survei atau eksploratif. Subjek penelitian diperoleh dengan pengambilan sampel tidak acak (non probability sampling) dengan metode consecutive sampling. Subjek yang mengisi lembar informed consent dan memenuhi kriteria inklusi berjumlah 35 orang yang terdiri dari dokter, perawat, laboran dan ahli gizi yang berinteraksi serta bekerja di RSUD Dr M Yunus Kota Bengkulu periode Juli-Desember 2020 dan terlibat dalam perawatan pasien COVID-19 secara langsung. Penelitian ini menggunakan kuesioner untuk melihat paparan waktu dan durasi subjek terpapar sinar matahari, cover tubuh/cara berpakaian, penggunaan pelindung tubuh (tabir surya/sunblock). Formulir recall 3x 24-h 2 hari aktif dan 1 hari libur berisi waktu, kegiatan, lokasi, durasi, pakaian yang digunakan, pelindung tubuh (tabir surya/sunblock) yang digunakan, serta dilakukan pemeriksaan laboratorium kadar Vitamin D plasma.

Data yang telah terkumpul di lapangan diperiksa oleh peneliti, bila terdapat kekurangan data pewawancara akan melengkapi dengan wawancara ulang kepada subjek penelitian. Jawaban pertanyaan dikoding oleh pewawancara sehingga mempermudah proses input data, selanjutnya data diinput ke komputer, dilanjutkan proses pembersihan data dengan melihat setiap sebaran data setiap variabel. Data yang telah dibersihkan selanjutnya dianalisis secara deskriptif (minimal, maksimal, rata-rata dan standar deviasi) dan statistik menggunakan software statistik yaitu SPSS.

Setelah didapatkan data hasil penelitian, data tersebut dianalisis dengan program software statistik untuk menguji normalitas data serta menguji hipotesis. Data yang diperoleh kemudian disajikan dalam bentuk tabel distribusi, frekuensi dan persentase kemudian dideskripsikan. Uji normalitas menggunakan uji shapiro-wilk untuk mengetahui distribusi data. Jika didapatkan data terdistribusi normal dilakukan uji pearson sedangkan jika data tidak terdistribusi normal dilakukan uji spearman. Kedua variabel dikatakan memiliki hubungan yang signifikan jika diperoleh nilai $\mathrm{p}<0,05$. 
HASIL PENELITIAN

Tabel. 1

Distribusi Frekuensi Karakteristik Subjek Penelitian

\begin{tabular}{lc}
\hline \multicolumn{1}{c}{ Karakteristik } & Frekuensi $(\mathrm{n}=37)$ \\
\hline Usia & \\
$-\quad 20-30$ tahun & $20(54,1 \%)$ \\
- $30-40$ tahun & $10(27 \%)$ \\
- $40-50$ Tahun & $5(13,5 \%)$ \\
- Diatas 50 Tahun & $2(5,4 \%)$ \\
\hline Jenis Kelamin & \\
- Laki-Laki & $11(29,70 \%)$ \\
- Perempuan & $26(70,30 \%)$ \\
\hline Pekerjaan & \\
- Dokter & $6(16,21 \%)$ \\
- Perawat & $25(67,56 \%)$ \\
- Ahli gizi & $3(8,1 \%)$ \\
- Laboran & $3(8,1 \%)$ \\
\hline Riwayat Penyakit & \\
- Alergi & $4(10,8 \%)$ \\
- Hipertensi & $1(2,70 \%)$ \\
- Dispepsia & $1(2,70 \%)$ \\
- Penyakit autoimun & $1(2,70 \%)$ \\
- Jantung, hipertensi, alergi & $1(2,70 \%)$ \\
- Tidak ada & $28(75,67 \%)$ \\
\hline Riwayat terinfeksi covid-19 & \\
- Ya & $6(16,22 \%)$ \\
- Tidak & $31(83,7 \%)$ \\
\hline Riwayat konsumsi suplemen & \\
- Ya Tidak & $32(86,47 \%)$ \\
\hline
\end{tabular}

Distribusi frekuensi data karakteristik berdasarkan usia, jenis kelamin, pekerjaan, indeks massa tubuh, berat badan, tinggi badan, riwayat paparan sinar matahari, riwayat terinfeksi COVID-19, riwayat penggunaan suplemen dapat dilihat pada tabel 1 . Berdasarkan informasi data riwayat paparan sinar matahari yang bervariasi. Secara ideal rekomendasi untuk berjemur perhari adalah 15-30 menit. Jumlah subyek dengan riwayat terpapar sinar matahari dengan rekomendasi sesuai adalah $48 \%$ dan yang memiliki riwayat paparan lebih dari rekomendasi sebanyak 27\%. Masih ada 24\% subyek yang memiliki paparan sinar matahari yang rendah yaitu dibawah 15 menit.

Tabel. 2

Riwayat Paparan Sinar Matahari

\begin{tabular}{lc}
\hline \multicolumn{1}{c}{ Variabel } & Frekuensi $(\mathrm{n}=37)$ \\
\hline Riwayat terpapar sinar matahari & $10(27 \%)$ \\
$-\quad 0-15$ menit & $16(43,2 \%)$ \\
$-\quad 15-30$ menit & $8(21,6 \%)$ \\
$-\quad 30-60$ menit & $2(5,4 \%)$ \\
$-\quad 1-3$ jam & $1(2,7 \%)$ \\
$-\quad$ Lebih dari 3 jam & \\
Kategorik paparan sinar matahari & $9(24,3 \%)$ \\
$-\quad 0-15$ menit & $18(48,6 \%)$ \\
$-\quad 15-30$ menit & $10(27 \%)$ \\
\hline
\end{tabular}


Berdasarkan hasil pemeriksaan kadar vitamin D hampir sebagian besar subyek penelitian yang merupakan tenaga kesehatan mengalami kondisi defisiensi 59,5\% dan insufisiensi sebanyak $37,8 \%$.

Tabel. 3

Riwayat Paparan Sinar Matahari

\begin{tabular}{lc}
\hline \multicolumn{1}{c}{ Variabel } & Frekuensi $(\mathrm{n}=37)$ \\
\hline Kadar vitamin D(OH)3 Darah & $17,55 \pm 6,19 \mathrm{ng} / \mathrm{mL}$ \\
- Defisiensi $(<20 \mathrm{ng} / \mathrm{mL})$ & $22(59,5 \%)$ \\
- Insufisiensi $(20-29 \mathrm{ng} / \mathrm{mL})$ & $14(37,8 \%)$ \\
$-\quad$ Normal $(>30 \mathrm{ng} / \mathrm{mL})$ & $1(2,7 \%)$ \\
\hline
\end{tabular}

Berdasarkan analisis hubungan antara sinar matahari, usia dan berat badan dengan kadar vitamin D menunjukkan bahwa tidak signifikan namun hal ini mengindikasikan adanya variable lain yang memengaruhi keadaan defisiensi pada tenaga kesehatan.

Tabel. 4

Hubungan Paparan Sinar Matahari dengan Kadar Vitamin D3 Darah

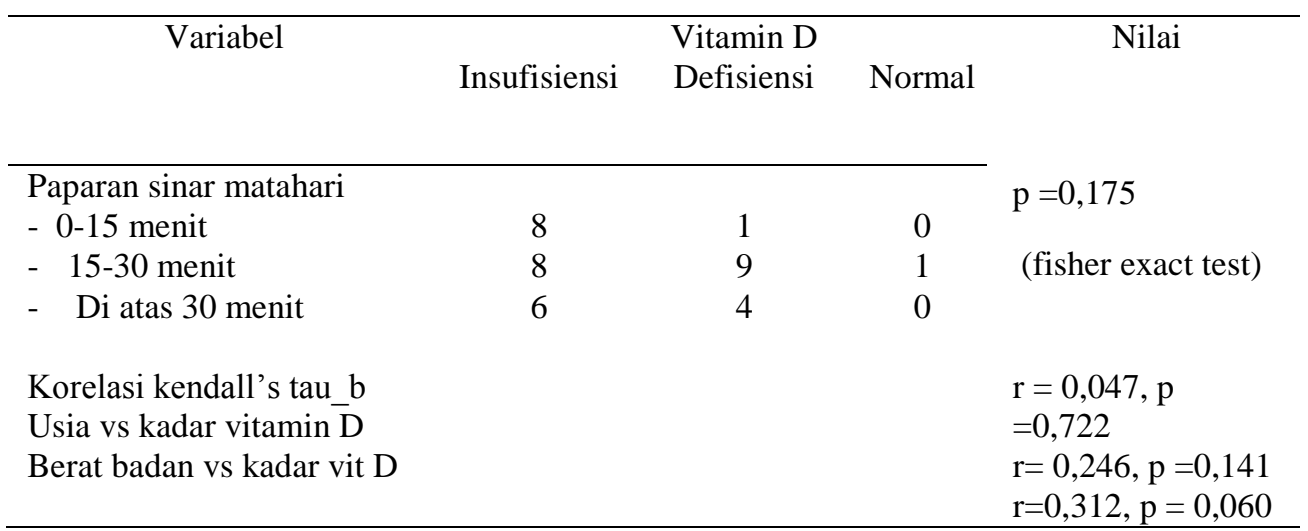

\section{PEMBAHASAN}

Hubungan Paparan Sinar Matahari dengan Kadar vitamin D3 Darah pada Tenaga Kesehatan Pelayanan COVID-19

Vitamin D berperan penting dalam sistem kekebalan tubuh. Vitamin D mengganggu sebagian besar sel sistem kekebalan tubuh seperti makrofag, limfosit B dan T, sel neutrofil dan sel dendritik, yang mengekspresikan VDR. Cathelicidin, sebuah peptida yang dibentuk oleh ekspresi terstimulasi vitamin $\mathrm{D}$, telah menunjukkan aktivitas antimikroba terhadap bakteri, jamur dan virus yang terselubung, seperti virus korona. Selanjutnya Vitamin D menghambat produksi sitokin proinflamasi dan meningkatkan produksi sitokin antiinflamasi. Metabolit aktif vitamin D dalam makrofag dan sel dendritik, berasal dari prekursor $25(\mathrm{OH}) \mathrm{D}$, mengarah ke aktivasi VDR, setelah RXR heterodimerisasi, menghasilkan ekspresi berbagai protein bawaan dan sistem imun adaptif (Sel Treg, sitokin, defensin, reseptor pengenalan pola, dan lain-lain). Vitamin D memberikan efek yang berlawanan pada sistem imun adaptif (penghambatan) dan bawaan (promosi). Hal ini berkorelasi dengan respons antiinflamasi dan menyeimbangkan respons imun (Razdan et al., 2020). 
Berdasarkan analisis hubungan antara sinar matahari, usia dan berat badan dengan kadar vitamin D menunjukkan bahwa tidak signifikan namun hal ini mengindikasikan adanya variabel lain yang memengaruhi keadaan defisiensi pada tenaga kesehatan. Keadaan defisiensi vitamin D pada subyek penelitian kemungkinan besar terjadi sejak lama karena sebagian besar tenaga kesehatan belum memerhatikan parameter imunologis secara baik.

Hasil studi menunjukkan bahwa kelompok paparan sinar matahari mengalami peningkatan konsentrasi serum $25(\mathrm{OH})$ D yang signifikan secara statistik, tetapi nilai absolut peningkatan ini kecil. Secara khusus, paparan sinar matahari selama 1 bulan gagal meningkatkan konsentrasi serum $25(\mathrm{OH}) \mathrm{D}$ di atas $20 \mathrm{ng} / \mathrm{mL}$ di sebagian besar populasi. Temuan ini menunjukkan bahwa pedoman saat ini untuk paparan sinar matahari yang direkomendasikan mungkin tidak cukup untuk meningkatkan kadar vitamin D ke konsentrasi yang memadai. Penelitian lain telah melaporkan peningkatan kadar serum $25(\mathrm{OH})$ D setelah 2-3 bulan terpapar sinar matahari, ada kemungkinan bahwa periode 1 bulan mungkin tidak cukup untuk memulihkan kadar vitamin D di antara orang dengan kekurangan vitamin D atau kekurangan (Razdan et al., 2020).

Penjelasan lain adalah bahwa kekurangan vitamin D dapat terjadi meskipun terpapar sinar matahari cukup karena penyebab yang tidak diketahui yang pada akhirnya menghalangi sintesis vitamin D. Karena prevalensi status vitamin D rendah tinggi bahkan di negara-negara yang terletak di sekitar ekuator di mana paparan sinar matahari melimpah sepanjang tahun dan karena paparan sinar matahari diperkirakan hanya menjelaskan $29 \%$ dari varian konsentrasi serum $25(\mathrm{OH})$ D selama pada periode musim panas hingga musim gugur di antara populasi lansia di negara Eropa. Lebih khusus lagi, selama proses sintesis vitamin D, paparan sinar matahari hanya terlibat pada langkah awal, konversi 7-dehidrokolesterol menjadi vitamin D3, yang terjadi di epidermis. Sintesis $25(\mathrm{OH})$ D, biomarker vitamin Kadar D pada manusia, membutuhkan 25hidroksilasi di hati dan pembentukan 1,25 $(\mathrm{OH}) 2 \mathrm{D}$, bentuk vitamin D yang aktif secara biologis, membutuhkan 1 $\alpha$-hidroksilasi di ginjal (Vranić et al., 2019).

Vitamin D bertanggung jawab untuk mengatur metabolisme kalsium dan fosfat dan menjaga kadar mineral tulang yang sehat. Vitamin ini juga dikenal sebagai hormon imunomodulator. Studi eksperimental telah menunjukkan bahwa 1,25-dihidroksivitamin $\mathrm{D}$, bentuk aktif vitamin $\mathrm{D}$, memberikan aktivitas imunologis pada banyak komponen sistem imun bawaan dan adaptif serta stabilitas membran endotel. Hubungan antara tingkat rendah serum 25-hidroksivitamin D dan peningkatan risiko pengembangan beberapa penyakit dan gangguan terkait kekebalan, termasuk psoriasis, diabetes tipe 1 , multipel sklerosis, rheumatoid arthritis, tuberkulosis, sepsis, infeksi saluran pernapasan, dan COVID-19 telah diamati.

Meskipun masih diperdebatkan tingkat serum 25-hidroksivitamin D yang optimal, disarankan untuk meningkatkan asupan vitamin D dan memiliki paparan sinar matahari yang masuk akal untuk menjaga serum 25-hidroksivitamin D minimal $30 \mathrm{ng} / \mathrm{mL}$ (75 nmol / L), dan sebaiknya pada 40-60 ng / mL (100-150 nmol / L) untuk mencapai manfaat kesehatan yang optimal dari vitamin D (Charoenngam \& Holick, 2020). Paparan UVR matahari, pada tingkat yang konsisten dengan aktivitas sehari-hari, dapat memengaruhi fungsi kekebalan secara langsung melalui kromofor yang ada di kulit atau secara tidak langsung, melalui peran sentralnya dalam sintesis prekursor vitamin D.

Hasil studi menunjukkan bahwa kelompok paparan sinar matahari mengalami peningkatan konsentrasi serum $25(\mathrm{OH})$ D yang signifikan secara statistik, tetapi nilai absolut peningkatan ini kecil. Secara khusus, paparan sinar matahari selama 1 bulan 
gagal meningkatkan konsentrasi serum $25(\mathrm{OH}) \mathrm{D}$ di atas $20 \mathrm{ng} / \mathrm{mL}$ disebagian besar populasi. Temuan ini menunjukkan bahwa pedoman saat ini untuk paparan sinar matahari yang direkomendasikan mungkin tidak cukup untuk meningkatkan kadar vitamin D ke konsentrasi yang memadai. Penelitian lain telah melaporkan peningkatan kadar serum $25(\mathrm{OH})$ D setelah 2-3 bulan terpapar sinar matahari, ada kemungkinan bahwa periode 1 bulan mungkin tidak cukup untuk memulihkan kadar vitamin D di antara orang dengan kekurangan vitamin D atau kekurangan (Lee et al., 2020).

Penjelasan lain adalah bahwa kekurangan vitamin D dapat terjadi meskipun terpapar sinar matahari cukup karena penyebab yang tidak diketahui yang pada akhirnya menghalangi sintesis vitamin D. Lebih khusus lagi, selama proses sintesis vitamin D, paparan sinar matahari hanya terlibat pada langkah awal, konversi 7-dehidrokolesterol menjadi vitamin D3, yang terjadi di epidermis. Sintesis $25(\mathrm{OH}) \mathrm{D}$, biomarker vitamin Kadar D pada manusia, membutuhkan 25-hidroksilasi di hati dan pembentukan 1,25 $(\mathrm{OH}) 2 \mathrm{D}$, bentuk vitamin D yang aktif secara biologis, membutuhkan $1 \alpha$-hidroksilasi di ginjal (Brouwer-Brolsma et al., 2016). Oleh karena itu, untuk mempertahankan status Vit D yang sesuai dan menurunkan angka kematian, diperlukan suplementasi untuk mengembalikan kadar Vitamin D yang berkurang.

\begin{tabular}{|c|c|}
\hline Variabel & Frekuensi $(n=37)$ \\
\hline Kadar vitamin $\mathrm{D}(\mathrm{OH}) 3$ Darah & $17,55 \pm 6,19 \mathrm{ng} / \mathrm{mL}$ \\
\hline - Defisiensi $(<20 \mathrm{ng} / \mathrm{mL})$ & $22(59,5 \%)$ \\
\hline - Insufisiensi (20-29 ng/mL) & $14(37,8 \%)$ \\
\hline - $\quad \operatorname{Normal}(>30 \mathrm{ng} / \mathrm{mL})$ & $1(2,7 \%)$ \\
\hline
\end{tabular}

Vitamin D bertanggung jawab untuk mengatur metabolisme kalsium dan fosfat dan menjaga kadar mineral tulang yang sehat. Vitamin ini juga dikenal sebagai hormon imunomodulator. Studi eksperimental telah menunjukkan bahwa 1,25-dihidroksi vitamin $\mathrm{D}$, bentuk aktif vitamin $\mathrm{D}$, memberikan aktivitas imunologis pada banyak komponen sistem imun bawaan dan adaptif serta stabilitas membran endotel. Hubungan antara tingkat rendah serum 25-hidroksi vitamin $\mathrm{D}$ dan peningkatan risiko pengembangan beberapa penyakit dan gangguan terkait kekebalan, termasuk psoriasis, diabetes tipe 1, multipel sklerosis, rheumatoid arthritis, tuberkulosis, sepsis, infeksi saluran pernapasan dan COVID-19 telah diamati. Oleh karena itu, sejumlah uji klinis yang bertujuan untuk menentukan kemanjuran pemberian vitamin $\mathrm{D}$ dan metabolitnya untuk pengobatan penyakit ini telah dilakukan dengan hasil yang bervariasi. Bukti terbaru menunjukkan bahwa beberapa individu mungkin mendapat manfaat dari vitamin D lebih atau kurang dari yang lain karena perbedaan antar-individu yang tinggi dalam ekspresi gen yang luas dalam sel mononuklear darah perifer manusia sebagai respons terhadap suplementasi vitamin D telah diamati. Meskipun masih diperdebatkan tingkat serum 25-hidroksi vitamin D yang optimal, disarankan untuk meningkatkan asupan vitamin $\mathrm{D}$ dan memiliki paparan sinar matahari yang masuk akal untuk menjaga serum 25-hidroksivitamin D minimal $30 \mathrm{ng} / \mathrm{mL}$ ( $75 \mathrm{nmol} / \mathrm{L}$ ), dan sebaiknya pada 40-60 ng / $\mathrm{mL}$ (100-150 nmol / L) untuk mencapai manfaat kesehatan yang optimal dari vitamin D (Slominski \& Postlethwaite, 2015).

Oleh karena itu, untuk mempertahankan status vitamin D yang sesuai dan menurunkan angka kematian, diperlukan suplementasi untuk mengembalikan kadar vitamin D yang berkurang akibat paparan sinar matahari yang tidak memadai. Saat ini tidak ada konsensus ilmiah tentang dosis optimal suplementasi vitamin D untuk 
COVID-19. Saat ini, The Institute of Medicine telah menetapkan tunjangan diet yang direkomendasikan, atau RDA, untuk vitamin D pada 600 Unit Internasional (IU) per hari untuk dewasa muda dan 800 IU per hari untuk orang dewasa yang berusia lebih dari 70 tahun.

Tetapi rekomendasi ini dikeluarkan dalam konteks kesehatan tulang. Berdasarkan studi observasi, konsentrasi minimal 40-50 ng/mL yang diinginkan. Studi lain melaporkan bahwa $38 \mathrm{ng} / \mathrm{mL}$ cocok untuk mengurangi risiko pneumonia yang didapat dari komunitas. Untuk mencapai kisaran konsentrasi di atas, dosis Vit D3 2000-5000 IU/hari dapat disuplementasi. Sebuah penelitian melaporkan peningkatan konsentrasi 25(OH)D3 dari $20 \pm 6$ menjadi $39 \pm 9 \mathrm{mg} / \mathrm{mL}$ untuk $4000 \mathrm{IU} /$ hari dan dari $19 \pm 4$ menjadi $67 \pm 3 \mathrm{ng} / \mathrm{mL}$ untuk $10.000 \mathrm{IU} /$ hari selama 8 minggu pemberian vitamin $\mathrm{D}$. Institut Kedokteran A.S. mencatat bahwa untuk dosis harian $<10.000 \mathrm{IU} /$ hari tidak ada efek samping yang dilaporkan untuk suplementasi vitamin D. Namun, nilai batas atas (UL) dikoreksi menjadi 4000 IU/hari berdasarkan semua penyebab kematian dan hasil penyakit kronis. Jadi, hasil-hasil bukti ilmiah merekomendasikan bahwa menjaga dosis harian vitamin D di bawah 4000 IU/hari dapat bermanfaat dalam meningkatkan kekebalan untuk memerangi infeksi COVID-19 secara lebih efektif (Slominski \& Postlethwaite, 2015).

\section{SIMPULAN}

Subjek penelitian kebanyakan adalah perawat. Riwayat penyakit yang terbanyak adalah riwayat alergi dan secara umum $75 \%$ tidak memiliki riwayat penyakit. Riwayat konfirmasi positif COVID-19 sebanyak 16\%. Jumlah subyek dengan riwayat terpapar sinar matahari dengan rekomendasi sesuai adalah $48 \%$, dan yang memiliki riwayat paparan lebih dari rekomendasi sebanyak 27\%. Masih ada 24\% subyek yang memiliki paparan sinar matahari yang rendah yaitu dibawah 15 menit. Berdasarkan hasil pemeriksaan kadar vitamin D hampir sebagian besar subyek penelitian yang merupakan tenaga kesehatan mengalami kondisi defisiensi 59,5\% dan insufisiensi sebanyak 37,8.

\section{SARAN}

Perlu dilakkan penelitian lebih lanjut untuk mngetahui paparan sinar matahari dan lamanya paparan yang tepat untuk mendapatkan vitamin $D$ yang lebih baik dibutuhkan oleh tubuh pada saat kondisi tubuh terserang oleh COVID 19.

\section{DAFTAR PUSTAKA}

Brouwer-Brolsma, E. M., Vaes, A. M. M., van der Zwaluw, N. L., Van- Wijngaarden, J. P., Swart, K. M. A., Ham, A. C., \& de Groot, L. C. P. G. M. (2016). Relative Importance of Summer Sun Exposure, Vitamin D Intake, and Genes to Vitamin D Status in Dutch Older Adults: The B-PROOF study. The Journal of Steroid Biochemistry and Molecular Biology, 164, 168-176. https://doi.org/10.1016/j.jsbmb.2015.08.008

Charoenngam, N., \& Holick, M. F. (2020). Immunologic Effects of Vitamin D on Human Health and Disease. Nutrients, 12(7), 2097. https://doi.org/10.3390/nu12072097

Coppeta, L., Papa, F., \& Magrini, A. (2018). Are Shiftwork and Indoor Work Related to D3 Vitamin Deficiency? A Systematic Review of Current Evidences. Journal of Environmental and Public Health, 2018, 1-7. https://doi.org/10.1155/2018/8468742 
Ebadi, M., \& Montano-Loza, A. J. (2020). Perspective: Improving Vitamin D Status in the Management of COVID-19. European Journal of Clinical Nutrition, 74(6), 856-859. https://doi.org/10.1038/s41430-020-0661-0

Ilie, P. C., Stefanescu, S., \& Smith, L. (2020). The Role of Vitamin D in the Prevention of Coronavirus Disease 2019 Infection and Mortality. Aging Clinical and Experimental Research, 32(7), 1195-1198. https://doi.org/10.1007/s40520-02001570-8

Laird, E., Rhodes, J., \& Kenny, R. A. (2020). Vitamin D and Inflammation: Potential Implications for Severity of Covid-19. Irish Medical Journal, 113(5). https://pubmed.ncbi.nlm.nih.gov/32603576/

Lee, Y.-M., Kim, S.-A., \& Lee, D.-H. (2020). Can Current Recommendations on Sun Exposure Sufficiently Increase Serum Vitamin D Level?: One-Month Randomized Clinical Trial. Journal of Korean Medical Science, 35(8). https://doi.org/10.3346/jkms.2020.35.e50

McGonagle, D., Sharif, K., O'Regan, A., \& Bridgewood, C. (2020). The Role of Cytokines including Interleukin-6 in COVID-19 induced Pneumonia and Macrophage Activation Syndrome-Like Disease. Autoimmunity Reviews, 19(6), 102537. https://doi.org/10.1016/j.autrev.2020.102537

Nakhaee, S., Ali Yaghoubi, M., Zarban, A., Amirabadizadeh, A., Faghihi, V., Yoosef Javadmoosavi, S., \& Mehrpour, O. (2019). Vitamin D Deficiency and Its Associated Risk Factors in Normal Adult Population of Birjand, Iran. Clinical Nutrition ESPEN, 32, 113-117. https://doi.org/10.1016/j.clnesp.2019.04.002

Parva, N. R., Tadepalli, S., Singh, P., Qian, A., Joshi, R., Kandala, H., \& Cheriyath, P. (2018). Prevalence of Vitamin D Deficiency and Associated Risk Factors in the US Population (2011-2012). Cureus. https://doi.org/10.7759/cureus.2741

Razdan, K., Singh, K., \& Singh, D. (2020). Vitamin D Levels and COVID-19 Susceptibility: Is there any Correlation? Medicine in Drug Discovery, 7, 100051. https://doi.org/10.1016/j.medidd.2020.100051

Slominski, A., \& Postlethwaite, A. E. (2015). Skin Under the Sun: When Melanin Pigment Meets Vitamin D. Endocrinology, 156(1), 1-4. https://doi.org/10.1210/en.2014-1918

Sowah, D., Fan, X., Dennett, L., Hagtvedt, R., \& Straube, S. (2017). Vitamin D Levels and Deficiency with Different Occupations: A Systematic Review. BMC Public Health, 17(1), 519. https://doi.org/10.1186/s12889-017-4436-z

Vanherwegen, A.-S., Gysemans, C., \& Mathieu, C. (2017). Regulation of Immune Function by Vitamin D and Its Use in Diseases of Immunity. Endocrinology and Metabolism Clinics of North America, 46(4), 1061-1094. https://doi.org/10.1016/j.ecl.2017.07.010

Vranić, L., Mikolašević, I., \& Milić, S. (2019). Vitamin D Deficiency: Consequence or Cause of Obesity? https://doi.org/10.3390/medicina55090541

Wu, D., Lewis, E. D., Pae, M., \& Meydani, S. N. (2018). Nutritional Modulation of Immune Function: Analysis of Evidence, Mechanisms, and Clinical Relevance. Frontiers in Immunology, 9, 3160. https://doi.org/10.3389/fimmu.2018.03160 